\title{
Characterization of muscarinic receptors mediating vasodilation in guinea-pig ileum submucosal arterioles by the use of computer-assisted videomicroscopy
}

\author{
Edwin Bungardt, Elisabeth Vockert, Roland Feifel, Ulrich Moser, Reinhold Tacke a, Ernst Mutschler, \\ Günter Lambrecht and Annmarie Surprenant ${ }^{\text {b }}$ \\ Department of Pharmacology, Unic crsity of Frankfurr. Theodor-Stern-Kai 7, Geb. 75A, D-6000 Frankfurt / Main, Germany, \\ "Institute of Inorganic Chemistry. Unicersity of Karlsruhe, Engesserstrasse, Geb. 30.45, D.7500 Karlsruhe, (jermany \\ and" The Vollum Institute, Oregon Health Sciences Unitersity, Portland, OR 47201. U.S.A.
}

Received 7 October 1991, revised MS received 26 November 1991, accepted 17 December 1991

\begin{abstract}
Muscarinic receptors of resistance vesscls (submucosal artcrioles, outside diameter $50-75 \mu \mathrm{m}$ ) from the guinea-pig small intestine were investigated in vitro using a computcr-assisted videomicroscopy system (Diamtrak ${ }^{\text {(F) }}$ ). The muscarinic receptor which mediates vasodilation of precontracted $[\mathrm{U}-46619(30) \mathrm{nM})$ or $(-)$-noradrenaline $(10 \mu \mathrm{M})]$ arterioles was characterized with several muscarinic agonists and subtype-sclectivc antagonists. The following agonists all produced cquivalent maximum vasodilation (given in rank order of potency): acctylcholinc $=$ arccaidine propargyl cster $(A P E)>$ oxotremorine $=( \pm)$-muscarinc $=( \pm)$-methacholine $>$ carbachol $>4-[[\mathrm{N}-(4$-chlorophenyl)carbamoyl $]$ oxy $]-2$-butynyltrimethylammonium iodide $(4-\mathrm{Cl}-\mathrm{McN}-\mathrm{A}$ 343). 4-[[N-(3-Chlorophenyl)-carbamoyl]oxy]-2-butynyltrimethylammonium chloride (McN-A-343) and N-ethyl-guvacine propargyl ester (NEN-APE) produced minimal or no arteriolar vasodilation. The muscarinic antagonists pirenzepinc, ( \pm )-5,11-dihydro-11[[[2-[2-((dipropylamino)methyl)-1-pipcridinyl]ethyl]amino]-carbonyl]-6H-pyrido(2,3-b)(1,4)-benzodiazcpin-6-onc (AF-DX 384), 11 [[4-[4-(dicthylamino)buty]]-1-piperidinyl]acety]]-5,11-dihydro-6H-pyrido(2,3-b)(1,4)-benzodiazepin-6-one (AQ-RA 741), p-fluorohexahydro-sila-difenidol (p-F-HHSiD), 4-diphenylacetoxy-N-methylpiperidine methiodide (4-DAMP) and (R)- and (S)hexahydro-difenidol [(R)-HHD, (S)-HHD] shifted the muscarinc, methacholine or carbachol dosc-responsc curve to the right in a competitive manner. Schild analysis of the data yiclded $\mathrm{pA}_{2}$ values for pircnzcpinc (6.74/6.9), AF-DX 384 (6.72), AQ-RA 741 (6.58), p-F-HHSiD (7.53/7.57), 4-DAMP (9.06), (R)-HHD (7.88/8.32) and (S)-HHD (5.52/5.88). Thus, it can be concluded that submucosal arterioles posscss only the $\mathbf{M}_{3}$ functional muscarinic receptor, the activation of which causes blood vessel dilation. The preparation described is considered to be a valuable ncw bioassay for pharmacological investigations of drug actions at muscarinic receptors in the peripheral vascular system.
\end{abstract}

Muscarinic receptor subtypes; Muscarinic receptor agonists $\left(\mathrm{M}_{1}\right.$-selective); Muscarinic receptor antagonists $\left(\mathrm{M}_{3}\right.$-selective); p-Fluoro-hexahydro-sila-difenidol; Smooth musclc (arteriolar); Submucosal plexus (guinea-pig);

Stereoselectivity (at muscarinic receptors); Vidcomicroscopy

\section{Introduction}

It is now generally accepted that three distinct muscarinic receptor subtypes can be distinguished by pharmacological mcans (Eglen and Whiting, 1986; Mitchelson, 1988; Levine and Birdsall, 1989; Lazareno et al., 1990; Lambrecht et al., 1989; Waelbroeck et al., 1989, 1990, 1991a). These three subtypes, termed $M_{1}, M_{2}$ and $M_{3}$ receptors, have also been shown to correspond to the structurally distinct cloned muscarinic receptors $\mathrm{m} 1, \mathrm{~m} 2$ and $\mathrm{m} 3$, respectively (Akiba et al., 1988; Bon-

Correspondence to: G. Lambrecht, Department of Pharmacology, University of Frankfurt, Theodor-Stern-Kai 7, Geb. 75A, D-6(100 Frankfurt/Main, Germany. Tel. 49.69.6301 6(1)77, fax 49.69.6301 6475. ner et al., 1987; Buckley et al., 1989; Dörje et al., 1991b). $M_{1}$ receptors appear to be located primarily on neuronal tissue, $M_{2}$ receptors have been most often localized in cardiac tissue, smooth muscle and lower brain areas and $\mathrm{M}_{3}$ receptors are found predominantly in exocrine glands and smooth muscle (Eglen and Whiting, 1986; Mitchelson, 1988; Lambrecht et al., 1989; Waelbroeck et al., 1990; Dörje et al., 1991a). There is a candidate $M_{4}$ receptor, found in rat striatum (Waelbroeck et al., 1990), rabbit lung (Lazareno et al., 1990) and NG108-15 cells (Michel et al., 1989; Caulfield and Brown, 1991), which is considered to be the m4 gene product (Dörje et al., 1991a; Brann et al., 1988).

Each of the three subtypes, $\mathbf{M}_{1}, \mathbf{M}_{2}$ and $\mathbf{M}_{3}$, can be identified in vascular preparations depending on the 
species, tissue and function examined. In general, $M_{3}$ receptors mediate EDRF-dependent relaxation, $M_{1}$ reccptors mediatc venous contraction and $M_{2}$ or $M_{3}$ receptors appear to inhibit noradrenaline overflow (Fernandes et al., 1991; for a review, see Eglen and Whiting, 1990). Recently, $M_{3}$ receptors have been implicated in endothelial-dependent vascular relaxation in the rabbit car artery and in bovine coronary artery, mediating both endothelial-dependent relaxation as wcll as endothelial-independent vascular contraction (Duckles and Garcia-Villalon, 1990; Brunner et al., 1991a,b).

Muscarinic receptors, whose activation produces vasodilation, have also been demonstrated in resistance vcssels of the gastrointestinal microcirculation, the submucosal arterioles of guinea-pig ileum (Neild ct al., 1990). These submucosal arterioles are innervated by cholinergic enteric neurones and these ncurones release acetylcholinc to produce pronounced vasodilation. This vasodilation is presumably caused by activation of $M_{3}$ receptors present on these blood vessels although it is not yet known whether muscarinic receptors reside on vascular smooth muscle directly or on the vascular endothelium (Neild et al., 1990).

The present experiments were undertaken to provide a detailed pharmacological characterization of the muscarinic receptor subtype which mediates the cholinergic vasodilation in submucosal arterioles of guinca-pig ileum. The in vitro submucosal arteriolar preparation uscd (Neild et al., 1990) allows the study of receptor-mediated vasodilation by means of a computer-assisted videomicroscopy system without the need to isolate individual segments of the vascular trec.

\section{Materials and methods}

The pharmacological experiments were performed at two different institutes [Portland (U.S.A.) and Frankfurt (F.R.G.)] using nearly identical hardware. For tcchnical reasons the experimental design used in Portland differed slightly from that in Frankfurt (see table 1). The data obtained in Portland are marked as 'method P' whereas those from Frankfurt are listed under 'method $F$ '.

\subsection{Tissue preparation}

Submucosal plexus preparations were obtained from the small intestine of guinea-pigs that had been killed by a blow on the head and exsanguinated. Preparations were dissected as described previously (Neild et al., 1990). Briefly, the mucosa was stripped from segments (8-12 mm long, 5-7 mm wide) of the small intestine and the submucosal plexus was pulled away from the underlying circular smooth muscle. The plexus was
TABLE 1

Experimental conditions used in Portland and Frankfurt (method $P$ and F) to determinc muscarinic effects in guinea-pig ileum submu. cosal arterioles. For further details, see text.

\begin{tabular}{|c|c|c|}
\hline & Method P & Method F \\
\hline Buffer: & $\begin{array}{l}\text { Physiological salinc } \\
(\mathrm{mM})\end{array}$ & $\begin{array}{l}\text { Tyrode stolution } \\
\text { (mM) }\end{array}$ \\
\hline $\mathrm{NaCl}$ & 126.0 & 137.00 \\
\hline $\mathrm{KCl}$ & 5.0 & 2.68 \\
\hline $\mathrm{CaCl}_{2}$ & 2.5 & 1.80 \\
\hline $\mathrm{MgCl}_{2}$ & 1.2 & 1.05 \\
\hline $\mathrm{NaHCO}_{3}$ & 25.0 & 11.90 \\
\hline $\mathrm{NaH}_{2} \mathrm{PO}_{4}$ & 1.2 & 0.42 \\
\hline D-Glucose & 11.0 & 5.05 \\
\hline Temperature: & $34-36^{\circ} \mathrm{C}$ & $32-34^{\circ} \mathrm{C}$ \\
\hline Preconstriction: & $\begin{array}{l}\mathrm{U}-46619 \\
\quad(285-30() \mathrm{nM})\end{array}$ & $\begin{array}{l}\text { Noradrenaline } \\
(10 \mu \mathrm{M})\end{array}$ \\
\hline Muscarinic agonist: & Muscarinc/carbachol & Methacholine \\
\hline
\end{tabular}

pinned onto transparent silicone rubber, mucosal surface down, in the base of a small organ bath (0.3-0.5 $\mathrm{ml}$ volume). The preparation consisted of arteriolar trecs, the outside diameters of which ranged from 50-75 $\mu \mathrm{m}$; tension applied to the connective tissue sheath resulted in approximately optimum-length conditions in the vascular network (Vanner et al., 1990). Physiological saline solution or Tyrode solution (for composition see table 1), gassed with $95 \% \mathrm{O}_{2}-5 \%$ $\mathrm{CO}_{2}$, flowed continuously at $32-36^{\circ} \mathrm{C}$ at $8-10 \mathrm{ml} / \mathrm{min}$. Preparations were equilibrated for $45-60)$ min prior to initiation of pharmacological experiments.

\subsection{Monitoring of arteriolar diameter}

The outside diameter of submucosal arterioles was monitored with the Diamtrak ${ }^{\text {* }}$ system as described previously (Neild, 1989; Neild et al., 1990). This system uses an Imaging Technology PCVisionPlus framegrabber board (Woburn, MA, U.S.A.) in an AT-compatible computer to digitize television images of outside edges of the arteriole and converts this result to an analog signal which is displayed on a conventional strip chart recorder. Resolution of the system was $<1$ $\mu \mathrm{m}$; the sampling rate was $10-20 \mathrm{~Hz}$.

\subsection{Agonist potencies}

To preconstrict the vessel, method $P$ used the thromboxane receptor agonist U-46619 at a concentration of 285-300 $\mathrm{nM}$, whereas in method $\mathrm{F}(-)$. noradrenaline $(10 \mu \mathrm{M})$ was used. Both agonists produced $80-90 \%$ of the maximum contractile response. The noradrenaline solution was freshly prepared before each experiment. No other precautions were taken 
to prevent oxidation of the catecholamine because of the high concentration used and the short duration of each experiment (Neild and Kotecha, 1989). All muscarinic agonists werc applied to preconstricted vessels by superfusion for 2-4 min (per agonist concentration) with a 20 -min washout period between applications. In initial experiments, all agonists were applied in a noncumulative fashion with 4-6 concentrations of agonist applied to each vesscl. In later experiments agonists wcre applied cumulatively because no significant differences werc found bctween concentration-response curves obtained by either of these methods. The apparent potency of a muscarinic agonist is expressed as its $\mathrm{EC}_{50}$ value, i.c. the molar concentration inducing $50 \%$ of the individual maximal vasodilation.

\subsection{Antagonist affinities}

Affinitics for muscarinic antagonists werc obtained by constructing concentration-response curves for agonists in the absence and then presence of two to four increasing concentrations of the antagonist. All antagonists were present for 12-15 min prior to agonist application. $\mathrm{EC}_{50}$ values were used to construct Schild plots, and slopes were obtained by least-squares fit. When slopes were not significantly different from unity, the $x$-intercept ( $\mathrm{pA}_{2}$ value) was obtained by fitting the best line with unit slope (Tallarida and Murray, 1986).

\subsection{Data analysis}

The data are presented as means \pm S.E.M. Differences between mean values were tested for statistical significance by using Student's t-test; $P<0.05$ was accepted as being significant.

\subsection{Drugs}

The following drugs were used: acetylcholine chloride, carbachol chloride, eserine hemisulfate, hexamethonium bromide, ( \pm )-muscarine chloride, oxotremorine sesquifumarate, sodium nitroprusside and tetrodotoxin (all from Sigma, St. Louis, U.S.A.); (-)noradrenaline hydrochloride (Fluka. Buchs, Switzerland); 9,11-dideoxy-11 $\alpha, 9 \alpha$-epoxy-methano-prostaglandin F2 (U-46619; Upjohn, Kalamazoo, U.S.A.); ( \pm )-methacholine chloride (EGA-Chemie, Steinheim, F.R.G.); 4-[[N-(3-chlorophenyl)-carbamoyl]oxy]-2butynyltrimethylammonium chloride (McN-A-343; Serva, Heidelberg, F.R.G.); 4-diphenylacetoxy-N-methylpiperidine methiodide (4-DAMP; Research Biochemicals Inc., Natick, U.S.A.); pirenzepine dihydrochloride, ( \pm )-5,11-dihydro-11-[[[2-[2-((dipropylamino)methyl)-1-piperidinyl]ethyl]amino]carbonyl]-6H-pyrido$(2,3-b)(1,4)$-benzodiazepin-6-one methanesulfonatc (AF-DX 384), 11-[[4-[4-(diethylamino)butyl]-1- piperidinyl]acetyl]-5, 11-dihydro-6H-pyrido(2,3-b)(1,4)benzodiazepin-6-one (AQ-RA 741), all provided by Thomac (Biberach, F.R.G.); the (R)- and (S)- cnantiomers of hexahydro-difenidol ((R)-HHD and (S). HHD; Tacke et al., 1989), ( \pm )-p-fluoro-hexahydrosila-difenidol (p-F-HHSiD; Tacke et al., 1991), arecaidine propargyl ester (APE; Mutschler and Hultzsch, 1973), N-cthyl-guvacine propargyl ester (NEN-APE; Wolf-Pflugmann et al., 1989) and 4-[[N-(4-chlorophenyl)-carbamoyl]oxy]-2-butynyltrimethylammonium iodide (4-Cl-McN-A-343; Nelson ct al., 1976) were synthesized in our laboratories. The other chemicals were of reagent grade and were used as purchased.

\section{Results}

\subsection{Agonists}

Figure 1 shows typical vasodilations produced by muscarinic agonists applied in a cumulative fashion to guinea-pig ileum submucosal arteriolar preparations. Maximum dilations produced by muscarine (fig. 1A) werc $84 \pm 8 \% \quad(n=43)$ and by methacholine $88 \pm 6 \%$ $(n=48)$ of the resting (non-constricted) outside diameter and this maximum response was not significantly different from the vasodilation produced by a supramaximal concentration of sodium nitroprusside $(20 \mu \mathrm{M}$; vasodilation $=79 \pm 6 \%, n=14$ ). All agonist effects were considered to be due to direct activation of muscarinic receptors on the submucosal artcrioles, and not to possible indirect activation of submucosal cholinergic neurones innervating the blood vessel, because responses were not altered in the presence of hexamethonium (100 $\mu \mathrm{M}, \mathrm{n}=8$ ) or tetrodotoxin $(0.5-1$ $\mu \mathrm{M}, \mathrm{n}=12$ ).

Acetylcholine, muscarine, methacholine, carbachol, APE, oxotremorine and 4-Cl-McN-A-343 dilated submucosal arterioles to the same maximum (fig. 2; data not shown for methacholine); $\mathrm{EC}_{50}$ values are shown in tablc 2. The acetylcholine-induced vasodilation was significantly enhanced in the presence of the cholinesterase inhibitor eserine $(1 \mu \mathrm{M})$, which produced an approximatcly two-fold shift to the left in the concentration-vasodilation curve (fig. 2A). Higher concentrations of cserine $(10$ and $100 \mu \mathrm{M})$ had no further effect $(n=5)$. Vasodilations produced by the agonists were maintained for the duration of agonist application and were reproducible in the same arteriole for up to 5 h during repeated applications at intervals of $20 \mathrm{~min}$. McN-A-343 and NEN-APE were virtually ineffective in producing arteriolar vasodilation; concentrations as high as $100 \mu \mathrm{M}$ produced less than $10 \%$ of the vasodilation evoked by application of the other agonists (figs. 1C and 2). 

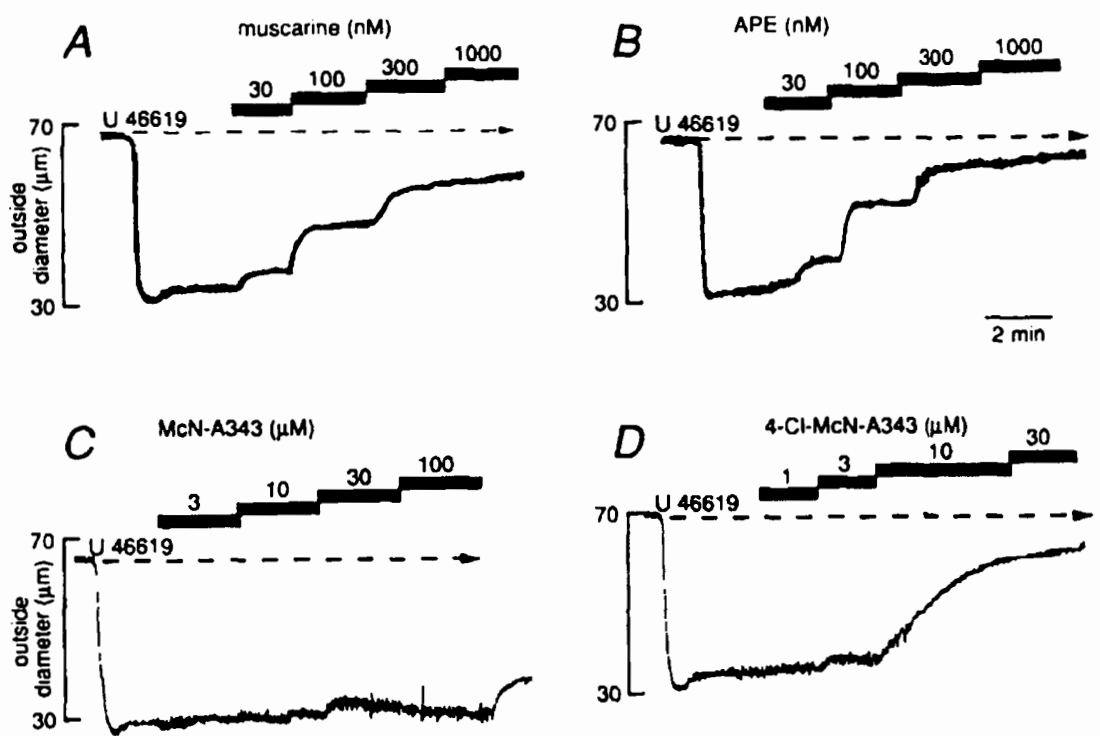

Fig. 1. Chart recordings of outside diameter of guinea-pig ileum submucosal arterioles preconstricted by 300 nM U.46619 during cumulative addition of muscarinic agonists to the superfusion solution. Vasodilations in response to muscarine (A), APE (B), McN-A-343 (C) and 4-Cl-McN-A-343 (D) are illustrated. Results in A through D obtained from different arterioles (method P).

TABLE 2

Potencies of agonists at muscarinic receptors in guinea-pig ileum submucosal arterioles and longitudinal smonth muscle. The data are presented as means \pm S.E.M., the numbers of experiments are given in parentheses. i.a. $=$ intrinsic activity.

\begin{tabular}{|c|c|c|c|}
\hline \multirow[t]{2}{*}{ Agonist } & \multicolumn{2}{|c|}{ Guinea-pig ilcum submucosal arteriole $\mathrm{EC}_{50}(\mathrm{nM})$} & \multirow{2}{*}{$\begin{array}{l}\text { Guinea-pig ileum longitudinal } \\
\text { smouth muscle } \mathrm{EC}_{50}(\mathrm{nM})\end{array}$} \\
\hline & Method P & Method F & \\
\hline Acetylcholine & $35 \pm 4(16)$ & - & $62^{\circ}$ \\
\hline Muscarine & $170 \pm 23(34)$ & - & $250^{\circ}$ \\
\hline Methacholine & - & $16(27)$ & $62^{\circ}$ \\
\hline APE & $40 \pm 9(13)$ & $8(7)$ & 170 \\
\hline NEN-APE & - & $>100000$ & inactive, $\mathrm{pA}_{2}=6.1^{\mathrm{c}}$ \\
\hline Carbachol & $450 \pm 26(29)$ & - & $100^{b}$ \\
\hline Oxotremorine & $185 \pm 20$ & - & $25^{b}$ \\
\hline 4-Cl-McN-A-343 & $4900 \pm 210$ & $18000 \pm 5000$ & $4000^{h}$ \\
\hline McN-A-343 & $>100000$ & $>100000$ & 10000, i.a. $=0.5^{h}$ \\
\hline
\end{tabular}

${ }^{a}$ Data from Mutschler et al. (1983). ${ }^{b}$ Data from Jokisch-Mehrling et al. (1989). ${ }^{\circ}$ Lambrecht et al., unpublished data. ${ }^{\mathrm{D}}$ Data from Moser et al. (1989). ' Data from Eltze et al. (1991), rat ileum.

\section{TABLE 3}

Affinity constants ( $\mathrm{pA}_{2}$ values) and slopes of Schild plots for antagonists at muscarinic receptors in guinea-pig ileum submucosal arterioles and longitudinal smooth muscle. The data are presented as means \pm S.E.M. of $6-19$ experiments.

\begin{tabular}{|c|c|c|c|c|c|}
\hline \multirow[t]{3}{*}{ Antagonist } & \multicolumn{4}{|c|}{ Guinea-pig ileum submucosal arteriole } & \multirow{3}{*}{$\begin{array}{l}\text { Guinea-pig ileum } \\
\text { longitudinal } \\
\text { smooth muscle } \\
\mathrm{pA}_{2}\end{array}$} \\
\hline & \multicolumn{2}{|l|}{ Method P } & \multicolumn{2}{|l|}{ Method F } & \\
\hline & $\mathrm{pA}_{2}$ & Slope & $\overline{\mathrm{pA}_{2}}$ & Slope & \\
\hline Pirenzepinc & $6.9^{\mathrm{a}}$ & & $6.74 \pm 0.06$ & $0.95 \pm 0.13$ & $6.9^{\mathrm{b}}$ \\
\hline AF-DX 116 & $5.9^{4}$ & & - & & $6.2^{\mathrm{c}}$ \\
\hline HHSiD & $8.5^{2}$ & & - & & $8.0^{\mathrm{h}}$ \\
\hline AF-DX 384 & - & & $6.72 \pm 0.04$ & $0.95 \pm 0.08$ & $7.6^{\mathrm{c}}$ \\
\hline AQ-RA 741 & - & & $6.58 \pm 0.05$ & $1.09 \pm 0.10$ & $6.6^{\mathrm{c}}$ \\
\hline p-F.HHSiD & $7.57 \pm 0.03$ & $1.04 \pm 0.11$ & $7.53 \pm 0.17$ & $0.70 \pm 0.11$ & $7.8^{\mathrm{b}}$ \\
\hline (R)-HHD & $8.32 \pm 0.04$ & $1.04 \pm 0.08$ & $7.88 \pm 0.10$ & $0.98 \pm 0.18$ & $8.4^{\mathrm{d}}$ \\
\hline (S)-HHD & $5.88 \pm 0.04$ & $0.99 \pm 0.11$ & $5.52 \pm 0.09^{c}$ & & $6.1^{\mathrm{d}}$ \\
\hline 4-DAMP & $9.06 \pm 0.05$ & $0.95 \pm 0.06$ & - & & $9.3^{r}$ \\
\hline
\end{tabular}

a Data from Neild et al. (1990). ${ }^{b}$ Data from Lambrecht et al. (1989). ${ }^{c}$ Data from Eberlein et al. (1989). ${ }^{d}$ Data from Feifel et al. (1990). ${ }^{c}$ Only two concentrations of (S)-HHD were investigated due to non-specific effects of the antagonist at higher concentrations. The pA 2 value was therefore determined from the individual dose ratios according to Tallarida et al. (1979). ' Data from Dörje et al. (1990). 

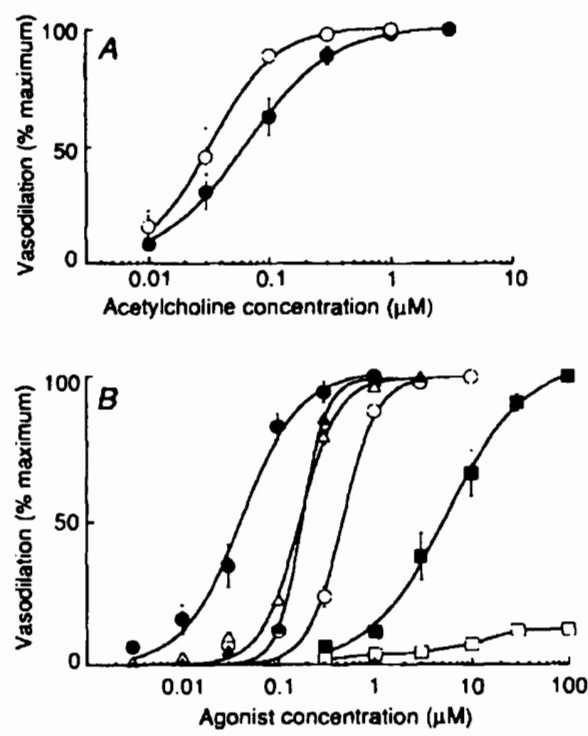

Fig. 2. Action of muscarinic agonists to dilate guinea-pig ileum submucosal arterioles (method $P$ ). $(\Lambda)$ Concentration-dilation curves for acetylcholine in the absence $(\bullet)$ and presence (O) of the cholinesterase inhibitor eserine $(1 \mu \mathrm{M}) ; n=5-10$ for each point. (B) Concentration-response curves for muscarinic agonists, APE (•), muscarine $(\Delta)$, oxotremorine $(\Delta)$, carbachol $(0), 4-\mathrm{Cl}-\mathrm{McN}-\mathrm{A}-343$ (ם) and McN-A-343 (ם); n = 9-24 for each point. All points are means \pm S.E.M. Some crror bars were within the width of the symbols.

\subsection{Antagonists}

The antagonists investigated all shifted the agonist concentration-vasodilation curves parallel to higher concentrations without any appreciable changes of pre-
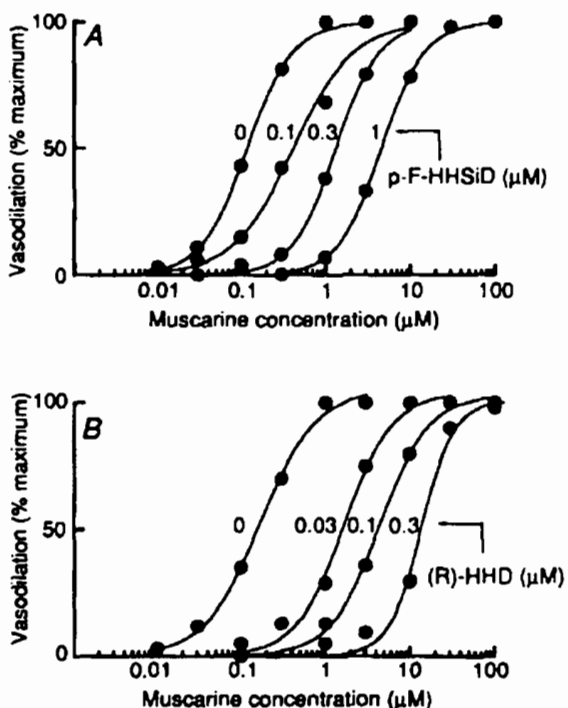

Fig. 3. Antagonism of muscarinic vasodilation by p-F-HHSiD (A) and (R)-HHD (B). Each graph shows data obtained from a single arteriole (one typical experiment), preconstricted with $300 \mathrm{nM}$ U-46619 (method P).
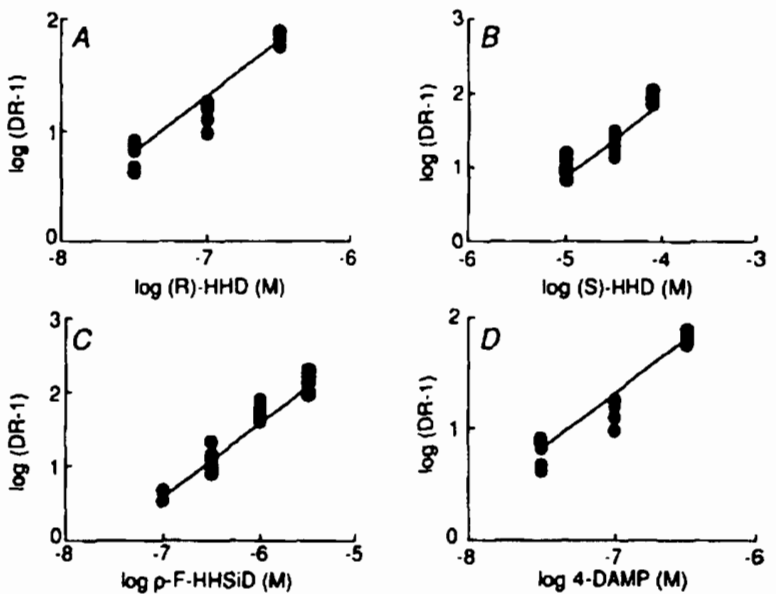

Fig. 4. Schild plots obtained for muscarinic antagonists at guinea-pig ileum submucosal arterioles preconstricted with 300 nM U-46619 using muscarine as agonist (method $P$ ). Log (dose ratio- 1 ) is plotted as a function of $\log [(R)-H H D](A), \log [(S)-H H D](B), \log [p-F$ $\mathrm{HHSiD}](C)$ or log [4-DAMP] (D). Lines are best fit lincar regression lines, using least-squares fits.

constriction or reduction of the maximum response. This is illustrated for p-F-HHSiD and (R)-HHD in fig. 3. The effects of 4-DAMP, (R)-HHD and p-F-HHSiD were readily reversible within $20-30 \mathrm{~min}$ of washout even at the highest concentrations used, while those of (S)-HHD werc slowly and, at the higher concentrations, only partially reversible (method P). Arunlakshana-Schild plots werc linear and slopes were not significantly different from unity, except in the case of p-F-HHSiD (method F: slope $=0.7$ ) and (S)-HHD (method P; using 10, 30, 100 and $300 \mu \mathrm{M}$ to construct the Schild plot). However, when the highest antagonist concentration $(300 \mu \mathrm{M})$ was omitted from the analysis, the slope was not significantly different from unity (table 3). Therefore, it was assumed that this very high concentration of (S)-HHD produced additional, nonspecific effects on submucosal arterioles. With method $F$ is was not possible to construct Schild plots for (S)-HHD because of similar nonspecific effects occurring at concentrations higher than $10 \mu \mathrm{M}$, which led to unstable declining preconstrictions. Thus, only two concentrations ( 3 and $10 \mu \mathrm{M})$ were investigated and the $\mathrm{pA}_{2}$ value was therefore determined from the individual dose ratios (Tallarida et al., 1979). The (R)enantiomer of HHD displayed 250- to 500-fold higher affinity than its corresponding (S)-isomer. Schild plots for 4-DAMP, (R)-HHD, (S)-HHD and p-F-HHSiD are shown in fig. 4 (method $P$ ). Table 3 summarizes antagonist $\mathrm{pA}_{2}$ values obtained from all experiments.

\section{Discussion}

Based on $\mathrm{pA}_{2}$ values obtained with pirenzepine, ( \pm )-11-[[2-[(diethylamino)methyl]-1-piperidinyl]acetyl]- 
5,11-dihydro-6H-pyrido(2,3-b)(1,4)-benzodiazepin-6-one (AF-DX 116) and hexahydro-sila-difenidol (HHSiD) (table 3; Neild et al., 1990), we had previously suggested that submucosal artcrioles of the guinea-pig ilcum possess the functional $M_{3}$ muscarinic receptor which mediates vasodilation.

This study was designed to characterize this muscarinic receptor further, using agonists and a larger number of subtype selective antagonists including one pair of enantiomers. The experiments were carried out at two institutes; the most important differences bctween the methods used in Portland and Frankfurt (method $\mathrm{P}$ and $\mathrm{F}$ ) were the use of $(-$ )-noradrenaline instead of U-46619 to preconstrict the vessels and methacholine instcad of muscarine or carbachol as muscarinic agonist for antagonist investigations. Furthermore there were minor differences in the concentration of $\mathrm{Ca}^{2+}$ and $\mathrm{K}^{+}$in the buffers $(1.8 \mathrm{vs} .2 .5 \mathrm{mM}$, 2.68 vs. $5 \mathrm{mM}$, respectivcly; table 1). However, both methods produced the same agonist potencies and antagonist affinitics (tables 2 and 3 ).

The results from the present study provide convincing cvidence that a single type of muscarinic receptor, the $M_{3}$ subtypc, mediates the cholinergic vasodilation in these submucosal arterioles.

The agonists used in the present experiments, with the exception of McN-A-343 and NEN-APE, acted as full agonists in producing arteriolar vasodilation. The rank order of potency was acetylcholine $=$ APE $>$ oxotremorine $=$ muscarine $=$ methacholine $>$ carbachol $>4-\mathrm{Cl}-\mathrm{McN}-\mathrm{A}-343$. This is the same agonist profile as observed in functional expcriments with the guinea-pig ilcal longitudinal smooth muscle preparation (table 2), the functional muscarinic receptor of which has been characterized as the $\mathrm{M}_{3}$ subtype. McN-A-343 was ineffective in producing vasodilation in submucosal arterioles. This is consistent with its incffectiveness in producing endothelial-dependent relaxation in rabbit ear artery or endothclial-independent contraction in bovine coronary artery (Duckles, 1988). McN-A-343 has been proposed to act as a sclective $M_{1}$ agonist (JokischMehrling et al., 1989) but exhibits variable responses at all muscarinic receptor subtypes, depending upon the receptor reserve of the preparation (Eglen and Whiting, 1986). The $M_{2}$ and $M_{3}$ activity reported varies from no agonistic action (Eglen et al., 1987) up to a partial agonism $\left(\mathrm{pD}_{2}=4.8\right.$ and 5.0, i.a. $=0.5$ at both $M_{2}$ and $M_{3}$ receptors (Jokisch-Mchrling et al., 1989)). The weak agonism at $M_{2}$ and $M_{3}$ receptors of McN-A343 might explain its very low activity at submucosal arterioles and may exclude the $M_{1}$ subtype for mediating the vasodilation. NEN-APE also shows an interesting activity profile at muscarinic receptors. At $M_{2}$ receptors it acts as a potent partial agonist (rabbit vas
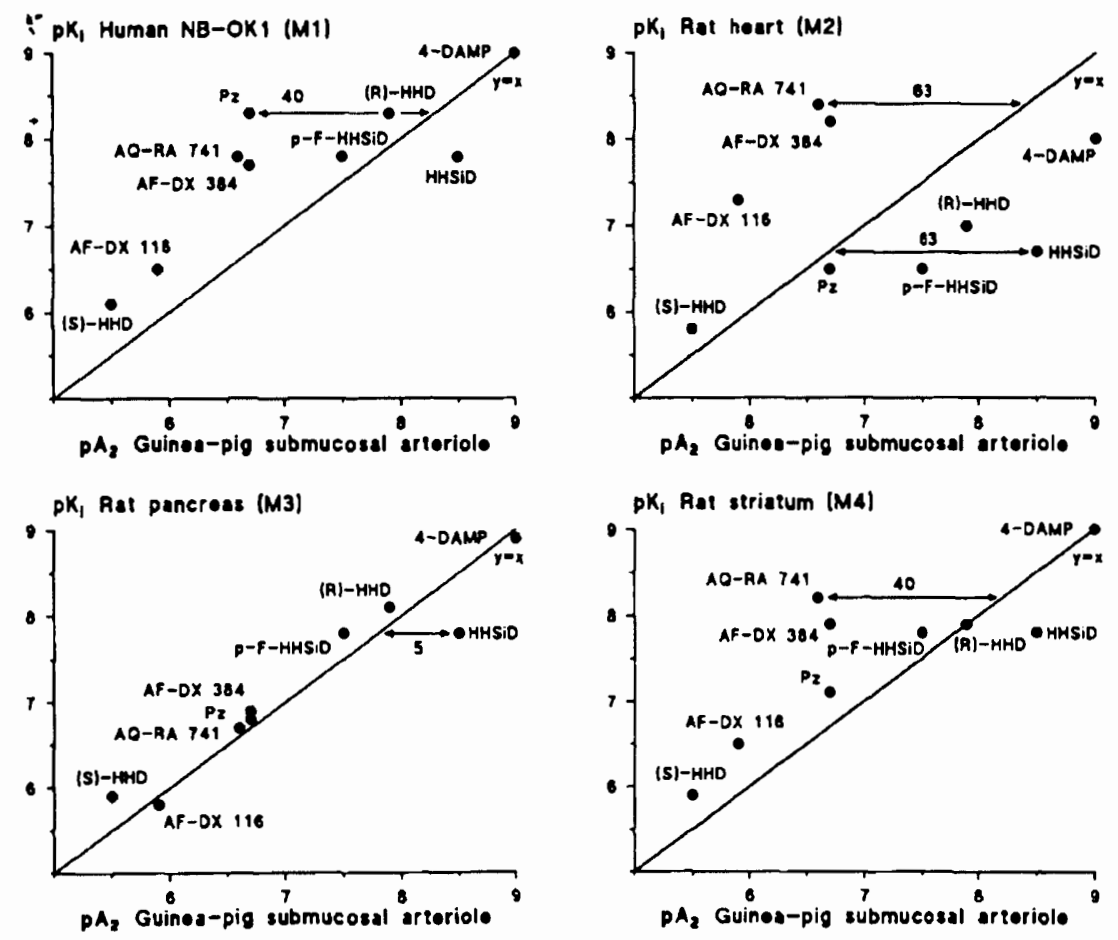

Fig. 5. Comparison of functional antagonist affinities ( $\mathrm{pA}_{2}$ values, table 3) obtained for pirenzepine (Pz), AF-DX 116, HHSiD, 4-DAMP, AF-DX 384, $\mathrm{Q}$-RA 741, p-F-IIHSiD, as well as (R)- and (S)-HHD, at guinea-pig ileum submucosal arterioles (this study and Neild et al., 1990) to the ir binding affinity $\left(\mathrm{pK}_{i}\right.$ values) determined in radioligand binding assays at $M_{1}, M_{2}, M_{3}$ and $M_{4}$ receptors (Waelbroeck ct al.. 1990, 199la.b and personal communication). 
deferens: $\mathrm{pD}_{2}=6.3$, i.a. $=1.1$ or rat left atrium: $\mathrm{pD}_{2}=$ 6.6, i.a. $=0.8$ ). At $M_{1}$ (rabbit vas deferens) and $M_{3}$ (rat ileum) receptors it behaves as a competitive antagonist $\left(\mathrm{pA}_{2}=5.8\right.$ and $\mathrm{pA}_{2}=6.1$, respectively) (Eltze et al. 1991). These findings might explain its lack of agonistic activity at muscarinic receptors in submucosal arterioles.

All antagonists investigated acted as pure competitive antagonists of the methacholine-, muscarine- or carbachol-induced vasodilation. Morcover, since the slopes of Arunlakshana-Schild regression lines did not significantly differ from unity (with cxception of p-FHHSiD, method $F$ ), the presence of a mixture of functional subtypes appears to be unlikely. Tablc 3 shows that there is a remarkable agreement in $\mathrm{pA}_{2}$ values for the antagonists studied in submucosal arterioles and in guinea-pig ilcum longitudinal smooth muscle preparations. It is also worth noting that these values are very similar to those obtained for the cloned m3 muscarinic reccptor (Dörje ct al., 1991b; Buckley ct al., 1989; Wess et al., 1991). Figure 5 shows a comparison of the $\mathrm{pA}_{2}$ values determined at submucosal arterioles and the corresponding binding affinities $\left(p K_{i}\right.$ values) obtaincd in radioligand binding assays at $M_{1}$, $M_{2}, M_{3}$ and $M_{4}$ receptors (data from Waelbroeck et al., 1990, 1991a,b, and personal communication). For receptor identity, the data points should not significantly deviate from the theoretical equality line $(y=x)$. The distance to this line (given in fig. 5 as antilog of the difference between $\mathrm{pA}_{2}$ and $\mathrm{pK}_{1}$ values) is a direct measure of receptor selectivity. The affinity of pirenzepine $\left(\mathrm{pA}_{2}=6.74\right)$ for the muscarinic receptor in submucosal arterioles was 40 -fold lower than that observed at $M_{1}$ (human NB-OK1 cells) receptors, thereby excluding the presence of functional $M_{1}$ receptors. The evident discrimination for AQ-RA 741 (63-fold lower than observed at $M_{2}$ and $4($ )-fold lower than determined at $\mathrm{M}_{4}$ reccptors), AF-DX 384 and HHSiD (63fold higher than observed at $M_{2}$ receptors) furthermore clearly excludes $M_{2}$ or $M_{4}$ receptors from mediating the vasodilation. A highly significant correlation was found for the $\mathrm{M}_{3}$ (rat pancreas) preparation only. Calculation of the eudismic index for the two enantiomers of HHD (method P: 2.44, method F: 2.36) and comparison of these values with data obtained in the same radioligand assay $\left(\mathrm{M}_{1}: 2.2, \mathrm{M}_{2}: 1.2, \mathrm{M}_{3}: 2.2, \mathrm{M}_{4}\right.$ : 2.0) also exclude the $M_{2}$ subtype and favour the $M_{3}$ subtype for mediating the vasodilation. Thus, it can be concluded that the functional muscarinic receptor mediating vasodilation in guinea-pig ileum submucosal arterioles is of the $\mathbf{M}_{3}$ subtype.

Depending on species, tissue and function measured, each of the three subtypes, $M_{1}, M_{2}$ and $M_{3}$, have been identified on vascular smooth muscle. In general, $M_{1}$ receptors mediate venous contraction, $\mathbf{M}_{2}$ or $M_{3}$ receptors appear to inhibit noradrenaline over- flow and direct EDRF-dependent relaxations are mediated in the majority of preparations by $\mathrm{M}_{3}$ receptors (Fernandes ct al., 1991; for a revicw, sce Eglen and Whiting, 1990). Recent studies report $M_{3}$ receptormediated rclaxation of the feline middle cercbral artery (Dauphin and Hamel, 1990) and of bovine coronary artery (Brunner et al., 1991a). In addition, a study of muscarinic relaxation in the rabbit ear artery has shown $\mathrm{pA}_{2}$ values for pircnzepine (6.8), AF-DX $116(6.0)$ and HHSiD (8.2) (Duckles and Garcia-Villalon, 1990) similar to those determined in submucosal arterioles (this study). Therefore our results obtained with muscarinic agonists and antagonists are in good agrecment with these carlier findings.

In conclusion, the present study investigated the muscarinic receptors of resistance vessels in guinea-pig ileum by the use of computer-assisted videomicroscopy. The muscarinic receptor which mediates vasodilation of the precontracted submucosal arterioles was characterized by detcrmining the potencies of a scries of muscarinic agonists and the affinities of various selective muscarinic antagonists. The results provide convincing evidence that a single type of muscarinic receptor, the $\mathrm{M}_{3}$ subtype, mediates the cholinergic vasodilation in submucosal arterioles of the guinea-pig ilcum. Thus, the application of computer-assisted videomicroscopy for tracking the diameter of small resistance vesscls (i.e. arterioles) is a useful new method for pharmacological investigations of drug actions at muscarinic receptors in the peripheral vascular system.

\section{Acknowledgements}

We thank M.-M. Jiang. C. I.emonidis and U. Hermanni for skillful technical assistance. The work was supported by National Institutes of llealth Grant HL 38940 (A.S.), the Fonds der Chemischen Industric (G.L., E.M., R.T.) and the Deutsche Forschungsgemeinschaft (G.L., R.T.)

\section{References}

Akiba. I., T. Kubo, A. Maeda. H. Bujo, J. Nakai, M. Mishina and S. Numa, 1988, Primary structure of porcine muscarinic acetyl. choline receptor III and antagonist binding studies, FEBS Lett. 235, 257.

Bonner, T.I., N.J. Buckley, A.C. Young and M.R. Brann, 1987, Identification of a family of muscarinic acetylcholine receptor genes. Science 237, 527.

Brann. M.R.. N.J. Buckley and T.I. Bonner, 1988, The striatum and cerebral cortcx express different muscarinic receptor mRNAs, FEBS Lett. 230, 90.

Brunner, F., E. Kühberger, K. Groschner, G. Pöch and W.R Kukovetz, 1991a, Characterization of muscarinic receptors mediating endothelium-dependent relaxation of bovine coronary artery, Eur. J. Pharmacol. 200, 25.

Brunner, F.. E. Kühberger. J. Schloos and W.R. Kukovetz, $1991 \mathrm{~b}$ Characterization of muscarinic receptors of hovine coronary artery 
by functional and radioligand binding studies, Eur. J. Pharmacol. 196, 247.

Buckley, N.J., T.I. Bonner, C.M. Buckley and M.R. Brann, 1989. Antagonist binding properties of five cloned muscarinic receptors expressed in CHO-K1 cells. Mol. Pharmacol. 35, 469.

Caulfield, M.P. and D.A. Brown, 1991. Pharmacology of the putative $\mathrm{M}_{4}$ muscarinic receptor mediating $C_{a}$-current inhibition in neuroblastoma $\times$ glioma hybrid (NG108-15) cells, Br. J. Pharmacol. $104,39$.

Dauphin, F. and E. Hamel, 1990, Muscarinic receptor subtype mediating vasodilation in feline middle cerebral artery exhibits M3 pharmacology, Eur. J. Pharmacol. 178, 203.

Dörje, F., T. Friebe, R. Tacke, E. Mutschler and G. Lambrecht. 199(), Novel pharmacological profile of muscarinic receptors mediating contraction of the guinea-pig uterus, Naunyn-Schmiedeb. Arch. Pharmacol. 342, 284.

Dörje, F., A.I. Levey and M.R. Brann, $1991 \mathrm{~d}$, Immunological detection of muscarinic receptor subtype proteins $\left(m_{1}-m_{5}\right)$ in rabbit peripheral tissues, Mol. Pharmacol. 48, 4.59.

Dörje, F., J. Wess, G. Lambrechı, R. Tacke, E. Mutschler and M.R. Brann, 1991b, Antagonist binding profiles of five cloned human muscarinic receptor subtypes. J. Pharmacol. Exp. Ther. 256, 727.

Duckles, S.P., 1988, Vascular muscarinic receptors: pharmacological characterization in the bovine coronary artery, J. Pharmacol. Exp. Ther. 246, 929.

Duckles. S.P. and A.L. Garcia-Villalon. 1990), Characterization of vascular muscarinic receptors: rabbit ear artery and bovine coronary artery, J. Pharmacol. Exp. Ther. 253, 608.

Eberlein, W.G., W. Engel, G. Mihm, K. Rudolf, B. Wetzel. M. Entzeroth, N. Mayer and H.N. Doods, 1989, Structure-activity relationships and pharmacological profile of sclective tricyclic antimuscarinics. Trends Pharmacol. Sci. 10 (Suppl.), 50).

Eglen, R.M. and R.L. Whiting, 1986, Muscarinic receptor subtypes: a critique of the current classification and a proposal for a working nomenclature, J. Auton. Pharmacol. 5, 323.

Eglen, R.M., B.Y. Kenny, A.D. Michel and R.L. Whiting, 1987. Muscarinic activity of $\mathrm{McN}-\mathrm{A}-343$ and its value in muscarinic receptor classification, Br. J. Pharmacol. 90. 693.

Eglen, R.M. and R.L. Whiting. 1990, Heterogeneity of vascular muscarinic receptors, J. Auton. Pharmacol. 19. 233.

Eltze. M., F. Dörje, H. Tietz, A. Immel, E. Mutschler and G. Lambrecht, 1991, Activity of N-ethyl-nor-arecaidine propargyl ester and (R)-nipecotic acid ethyl ester at pre- and postsynaptic muscarinic receptor subtypes, in: Presynaptic receptors and neuronal transporters, Advances in the Biosciences, Vol. 82, eds. S.Z. Langer, A.M. Galzin and J. Costentin (Pergamon Press, Oxford) p. 33.

Feifel, R., M. Wagner-Röder, C. Strohmann, R. Tacke, J. Waelbroeck, J. Christophe, E. Mutschler and G. Lambrecht, 1990. Stereoselective inhibition of muscarinic receptor subtypes by the enantiomers of hexahydro-difenidol and acetylenic analogues, $\mathrm{Br}$. J. Pharmacol. 99, 455.

Fernandes, F.A., M.J. Alonso, J. Marin and M. Salaices, 1991 $M_{3}$-Muscarinic receptor mediates prejunctional inhibition of noradrenaline release and the relaxation in cat femoral artery, J. Pharm. Pharmacol. 43, 644.

Jokisch-Mehrling, B., R. Feifel, M. Eltze, J.F. Rodrigues de Miranda, G. Lambrecht and E. Mutschler, 1989, M1-Potencies of muscarinic agonists in rabbit isolated vas deferens. Trends Pharmacol. Sci. 10 (Suppl.), 109.

Lambrecht, G., R. Feifel, M. Wagner-Röder, C. Strohmann, H. Zilch, R. Tacke. M. Waelbroeck, J. Christophe, H. Boddeke and E. Mutschler, 1989, Affinity profiles of hexahydro-sila-difenidol analogues at muscarinic reccptor subtypes, Eur. J. Pharmacol. $168,71$.

Lazareno, S., N.J. Buckley and F.F. Roberts, 1990, Characterization of muscarinic $\mathrm{M} 4$ binding sites in rabbit lung, chicken heart, and NG108-15 Cells. Mol. Pharmacol. 38, 805 .
Levinc, R.R. and N.J.M. Birdsall (eds.), 1989, Subtypes of muscarinic receptors IV, Trends Pharmacol. Sci. 10 (Suppl.).

Michel, A.D., R. Delmendo, E. Stefanich and R.L. Whiting, 1989 , Binding characteristics of the muscarinic receptor subtype of the NGI08-15 cell line, Naunyn-Schmiedeb. Arch. Pharmacol. 340. 62.

Mitchelson, F., 1988, Muscarinic receptor differentiation, Pharmacol. Ther. 37, 357.

Moser, U., G. Lambrecht, M. Wagner, J. Wess and E. Mutschler, 1989. Structurt-activity relationships of new analogues of arecaidine propargyl ester at muscarinic $M_{1}$ and $M_{2}$ receptor subtypes, Br. J. Pharmacol. 96. 319.

Mutschler, E. and K. Hultzsch, 1973, Über Struktur-Wirkungs-Beziehungen von ungesättigten Estern des Arecaidins und Dihydroarecaidins, Arzneim. Forsch. 23, 732.

Mutschler, E., H.-D. Höltje, G. Lambrecht and U. Moser, 1983. Struktur- und Konformations-Wirkungs-Bezichungen helerozyklischer Acetylcholin-Analoga, Arzneim. Forsch. 33, 806.

Neild. T.O., 1989. Measurement of arteriole diameter changes by analysis of television images, Blood Vessels 26, 48.

Neild, T.O. and N. Kotecha, 1989. A study of the phasic response of arterioles of the guinea pig small intestine to prolonged exposure to norepinephrine, Microvasc. Res. 38, 186.

Neild, T.O., K.-7. Shen and A. Surprenant, 1990, Vasodilation of arterioles by acetylcholine released from single neurones in the guinea-pig submucosal plexus, J. Physiol. (London) 420. 247.

Nelson, W.L., D.S. Freeman and F.F. Vinzenzi, 1976. Stereochemical analogs of a muscarinic, ganglionic stimulant, 2. Cis and trans olefinic. epoxide, and cyclopropane analogs related to $4-[\mathrm{N}-(3$ chlorophenyl)carbamoyloxy\}-2-butynyltrimethylammonium chloride (McN-A-343), J. Med. Chem. 19, 153.

Tacke, R., C. Strohmann, S. Sarge. H.K. Cammenga, D. Schomburg, E. Mutschler and $G$. Lambrecht, 1989. Preparation and properties of the enantiomers of the selective antimuscarinic agent 1-cyclohexyl-1-phenyl-4-piperidino-1-butanol (hexahydro-difenidol). Liehigs Ann. Chem. 137.

Tacke, R.. K. Mahner, C. Strohmann, B. Forth, E. Mutschler, T Friebe and G. Lambrecht, 1991, Cyclohexyl(4-fluorophenyl)(3piperidinopropyl)silanol ( $p$-fuoro-hexahydro-sila-difenidol, $p$-FHHSiD) and derivatives: Synthesis and antimuscarinic properties, J. Organomet. Chem. 417, 339.

Tallarida, R.J.. A. Cowan and M.W. Adler, 1979, pA, and receptor differentiation: A statistical analysis of compctitive antagonism, Life Sci. 25, 637.

Tallarida, R.J. and R.B. Murray, 1986, Manual of Pharmacologic Calculations with Computer Programs, 2nd cdn. (Springer-Verlag. Berlin).

Vanner, S., M.-M., Jiang. V.L. Broxks and A. Surprenant, 1990. Characterization of vasopressin actions in isolated submucosal arterioles of the intestinal microcirculation, Circ. Res. 67, 1017.

Waelbroeck, M., M. Tastenoy, J. Camus, J. Christophe, C. Strohmann, H. Linoh, H. Zilch, R. Tacke, E. Mutschler and G. Lambrecht, 1989. Binding and functional properties of antimuscarinics of the hexocyclium/sila-hexocyclium and hexahydro-diphenidol/hexahydro-sila-diphenidol type to muscarinic receptor subtypes, Br. J. Pharmacol. 98, 197.

Waelbroeck, M.. M. Tastenoy, J. Camus and J. Christophe, 1990. Binding of selective antagonists to four muscarinic receptors $\left(M_{1}\right.$ io $\mathrm{M}_{4}$ ) in rat forebrain, Mol. Pharmacol. 38, 267.

Waelbrocck, M.. J. Camus, M. Tastenoy, E. Mutschler, C. Strohmann, R. Tacke, G. Lambrecht and J. Christophe, 1991 a, Binding affinities of hexahydro-difenidol and hexahydro-sila-difenidol analogues at four muscarinic recepıor subtypes: constitutional and stereochemical aspects. Eur. J. Pharmacol. Mol. Pharmacol. 206, 95.

Waelbroeck, M., J. Camus. M. Tastenoy, E. Mutschler. C. Strohmann, R. Tacke, (j. Lambrecht and J. Christophe, 1991b. Stereoselectivity of (R)- and (S)-hexahydro-difenidol binding to neuroblastoma 
$M_{1}$, cardiac $M_{2}$, pancreatic $M_{3}$ and striatum $M_{4}$ muscarinic receptors, Chirality $3,118$.

Wess, J., G. Lambrecht, E. Mutschler, M.R. Brann and F. Dörje, 1991, Selectivity profile of the novel muscarinic antagonist UH$\mathrm{AH} 37$ determined by the use of cloned receptors and isolated tissue preparations, Br. J. Pharmacol. 102, 246.
Wolf-Pflugmann, M., G. I ambrechi, J. Wess and E. Mutschler, 1989. Synthesis and muscarinic activity of a series of tertiary and quaternary guvacine esters structurally related to arecoline and arecaidine propargyl ester. Arzneim. Forsch. 39, 5.39. 